\title{
Zika virus detection in cerebrospinal fluid from two patients with encephalopathy, Martinique, February 2016
}

B Rozé ${ }^{1}$, F Najioullah ${ }^{23}$, A Signate ${ }^{4}$, K Apetse ${ }^{5}$, Y Brouste $^{6}$, S Gourgoudou ${ }^{6}$, L Fagour $^{2}$, S Abel $^{13}$, P Hochedez $^{13}$, R Cesaire $^{2}$

3, A Cabié ${ }^{137}$, on behalf of the Neuro-Zika Working Group of Martinique ${ }^{8}$

1. Infectious and Tropical Diseases Department, University Hospital of Martinique, Fort-de-France, France

2. Laboratory of Virology, University Hospital of Martinique, Fort-de-France, France

3. Université des Antilles, EA4537, Fort-de-France, France

4. Neurology Department, University Hospital of Martinique, Fort-de-France, France

5. Electrophysiological Department, University Hospital of Martinique, Fort-de-France, France

6. Emergency Department, University Hospital of Martinique, Fort-de France, France

7. INSERM CIC1424, Fort de France, France

8. The members of the group are listed at the end of the article

Correspondence: Benoît Rozé (benoit.roze@chu-fortdefrance.fr)

Citation style for this article:

Rozé B, Najioullah F, Signate A, Apetse K, Brouste Y, Gourgoudou S, Fagour L, Abel S, Hochedez P, Cesaire R, Cabié A, on behalf of the Neuro-Zika Working Group of Martinique. Zika virus detection in cerebrospinal fluid from two patients with encephalopathy, Martinique, February 2016. Euro Surveill. 2016;21(16):pii=30205.

DOI: http://dx.doi.org/10.2807/1560-7917.ES.2016.21.16.30205

Article submitted on 04 April 2016 / accepted on 21 April 2016 / published on 21 April 2016

We report two cases of encephalopathy (one with seizures, one with electroencephalogram changes) in patients with Zika virus infection. The cases occurred on Martinique in February 2016, during the Zika virus outbreak. Awareness of the various neurological complications of Zika virus infection is needed for patients living in areas affected by Zika virus infections or for travellers to these areas.

We describe two cases of encephalopathy in patients with Zika virus infection detected on Martinique in February 2016. In both patients, Zika virus RNA was detected in their cerebrospinal fluid (CSF), plasma, and urine.

\section{Description of the cases}

Case 1

At the end of February 2016, two months after the detection of the first Zika virus-positive cases on Martinique, a previously healthy young adult was admitted to the University Hospital of Martinique, after having experienced an episode of convulsive seizures that occurred six hours after the onset of a dengue-like syndrome (fever, arthralgia, asthenia and headache). Upon initial clinical evaluation, the patient was febrile, with a low level of consciousness (Glasgow coma scale (GCS) 9) and no neurological focal signs. After direct intravenous injection of clonazepam (one milligram), the patient recovered to a normal level of consciousness (GCS 15). The patient was hospitalised for three days, then returned back home with symptomatic treatment of acetaminophen and codeine against headache and arthralgia. One week later, clinical assessment found no new neurological symptoms, but headache and arthralgia persisted for 45 days.

Brain magnetic resonance imaging (MRI) and videoelectroencephalogram (EEG) performed on day 5 after onset of neurological symptoms, were normal.

Laboratory findings at onset of neurological symptoms showed normal blood count and a sterile CSF with no white blood cells (norm: $\langle 10 / \mathrm{ml}$ ), and $0.20 \mathrm{~g} / \mathrm{L}$ protein (norm: 0.15-0.40). The glycorachia/glycaemia ratio was normal (norm: >0.5).

The patient was screened for the common aetiologies of viral encephalitis: test results for herpes simplex virus, varicella zoster virus and cytomegalovirus (CMV) by PCR were negative in CSF. Direct detection in CSF of enterovirus, dengue virus (DENV) and chikungunya virus by real-time RT-PCR were negative. Serological tests for HIV, CMV and venereal research disease laboratory (VDRL) were negative. Serology for toxoplasmosis was positive in IgG. Direct detection of Leptospira sp. in plasma by PCR was negative. Cryptococcus sp. antigenemia in serum was negative. Detection of Zika virus by real-time RT-PCR in plasma, cerebrospinal fluid and urine were positive (Table).

\section{Case 2}

In the last week of February 2016, a patient in their late $70 \mathrm{~s}$ was brought to the University Hospital of Martinique by their family who reported symptoms including acute mental confusion, speech disorder, 
TABLE

Clinical, neuroimaging, electroencephalography and microbiological findings in two cases of encephalopathy associated with Zika virus infection, Martinique, February 2016

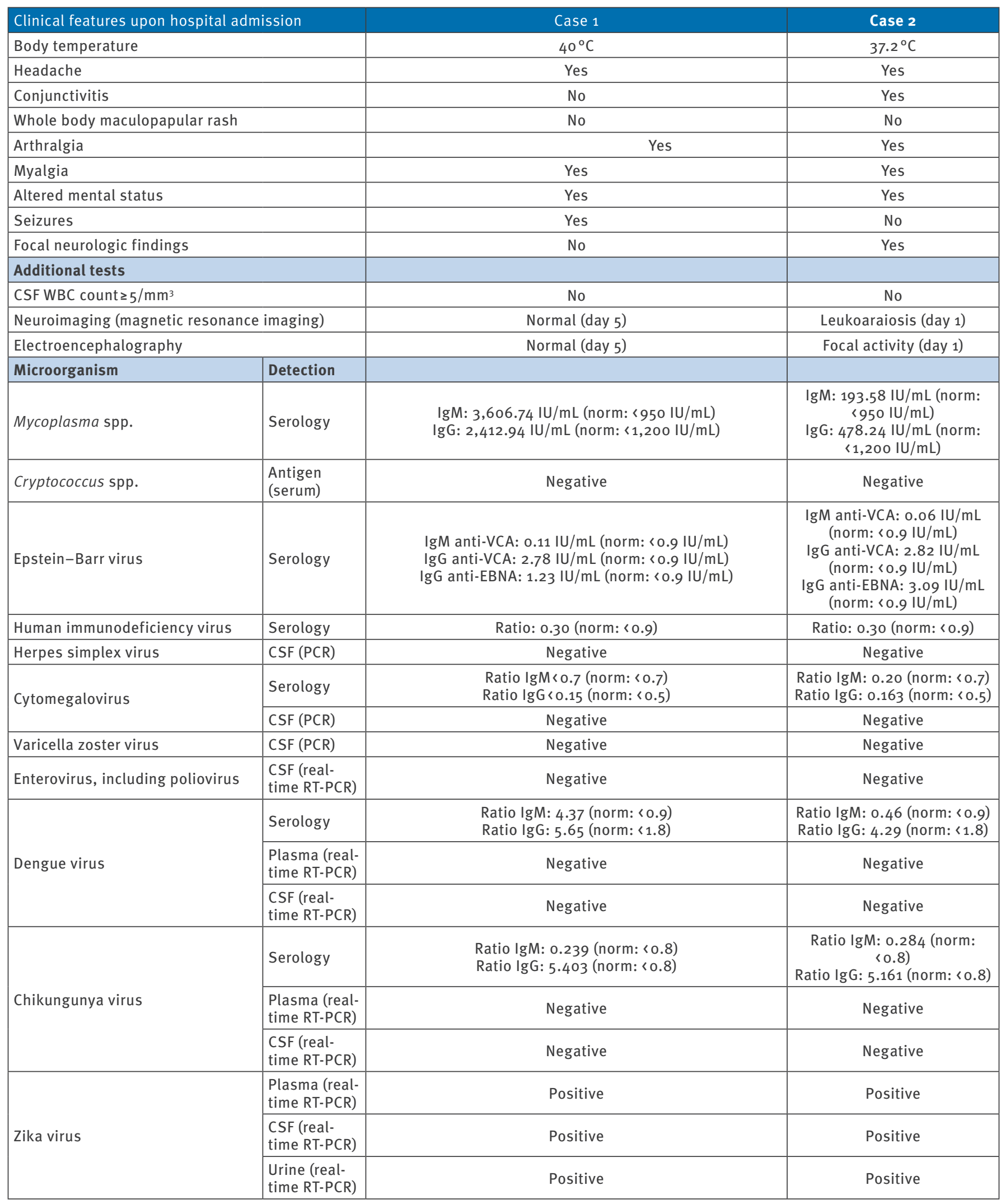

CSF: cerebrospinal fluid; EBNA: Epstein-Barr nuclear antigen; IU: international unit; VCA: viral capsid antigen; WBC: white blood cell count. 
and right facial palsy, which had started three hours before hospital admission. Upon initial clinical evaluation the patient was afebrile and aphasic; conjunctivitis, bilateral hands oedema, and peripheral arthritis were present. Facial palsy was not noticed upon clinical examination. Aphasia resolved spontaneously 45 minutes after the first clinical evaluation.

Upon initial clinical evaluation, brain MRI was only consistent with leukoaraiosis, and EEG revealed an unequivocal asymmetry with abnormal left frontotemporal slow waves. These waves were consistent with the presence of a pathological process, but had no specific pattern. The EEG performed one week later showed almost complete regression of the slow waves.

The analysis of CSF showed a protein count of $0.40 \mathrm{~g} / \mathrm{L}$ and a white blood cell count of $2 / \mathrm{mL}$. The glycorachia/ glycaemia ratio was normal. PCR for common aetiologies of encephalitis was negative. Detection of Zika virus by real-time RT-PCR in plasma, CSF and urine gave a positive result (Table).

\section{Discussion}

Since December 2015, an outbreak of Zika virus infections has been ongoing on Martinique, a French West Indies island of 390,000 inhabitants. It spread rapidly, with more than 15,400 cases estimated as at 31 March 2016 [1]. Zika virus infection is usually benign, when symptomatic. The disease resembles uncomplicated dengue fever and lasts for four to seven days and is self-limiting. In Martinique, Aedes aegypti is assumed to be the unique vector of flaviviruses. Recent Zika virus epidemics in French Polynesia, Brazil, Central America and the French West Indies have been associated with neurological complications [2].

Over the past five years, there have been between one and three patients with encephalitis hospitalised monthly in the University Hospital of Martinique.

In this report, we present two cases of encephalopathy fulfilling the diagnostic criteria of the Consensus Statement of the International Encephalitis Consortium [3]. Based on the laboratory findings, we consider these cases as Zika virus-associated. In keeping with neurological findings in other arbovirus infections, the presentations were of non-specific nature; the spectrum of arboviral neurological disease may even lead to ischemic stroke [4]. Moreover, in arbovirus-related neurological disorders, imaging findings may be normal and different EEG abnormalities can be seen [5]. Zika virus is known as a neurotropic microorganism [6], however, both structural imaging and EEG can be normal in acute infection [5]. The mechanism of flavivirus infection of the central nervous system (CNS) is not clearly understood and pathology depends on the virus. Neurological involvement can be caused by direct damage of the nerve by the virus but also be immune mediated. For example, dengue virus can infect human astrocytes and brain microvascular endothelial cells, whereas West Nile virus infection could lead to a bloodbrain barrier dysfunction [7].

Awareness of the wide spectrum of neurological symptoms of Zika virus infection is needed for patients living in, or travelling to areas affected by Zika virus infections. Knowledge of the pathophysiology of Zika virus infection and the reasons behind its predilection for the CNS is needed to design treatment strategies to mitigate significant morbidity.

\section{Neuro-Zika Working Group}

Dr. Gwenole Abgrall, Dr. Véronique Aïm, Dr. Alessandro Arrigo, Prof. Philippe Cabre, Dr. Cyrille Chabartier, Dr. Sylvie Colombani, Dr. Julien Cuziat, Dr. Nicole Desbois, Prof. Régis Duvauferrier, Dr. Jean-Louis Fergé, Dr. Karine Guitteaud, Dr. Ingrid Laudarin, Dr. Séverine Jeannin, Dr. Joux Julien, Dr. Sandrine Julié, Dr. Hossein Mehdaoui, Dr. Mehdi Mejdoubi, Dr. Charline Miossec, Dr. Claude Olive, Dr. Karine Pailla, Dr. Sandrine Pierre-François, Dr. Mathilde Pircher, Dr. Alain Putot, Dr. Dabor Resiere, Dr. Christiane Richer, Dr. JeanRomain Risson, Dr. Marie Sabia, Dr. Michel Schloesser, Dr. Rafaelle Théodose, Dr. Ruddy Valentino, Dr. Rosalie Vilain.

\section{Acknowledgements}

This work was sponsored by the University Hospital of Martinique for regulatory and ethic submission.

This work was supported by a grant from the Clinical Research Hospital Program from the French Ministry of Health (PHRC 2009).

\section{Conflict of interest}

None declared.

\section{Authors' contributions}

$B R, K A, F N, S A, P H, A C$ wrote the manuscript.

BR, PH, AS, KA, YB, SG and the Neuro-Zika Working Group took part in the clinical management of the patients.

FN, RC collaborated in molecular biology techniques.

LF, RC, FN collaborated on the serological techniques.

All authors participated in the outbreak investigation.

All authors read and approved the final manuscript.

\section{References}

1. Antilles Guyane CIRE. Emergence du virus Zika aux Antilles Guyane. [Outbreak of Zika virus in Antilles Guyane]. Le point épidémiologique, CIRE Antilles Guyane. 2016;12:1-8. French. Available from: http://www.invs.sante.fr/content/ download/124427/441931/version/106/file/pe_zika_antilles_ guyane_010416.pdf

2. Pan American Health Organization / World Health Organization. Zika Epidemiological Update - 14 April 2016. Washington, D.C.: PAHO/WHO; 2016. Available from: http:// www.paho.org/hq/index.php?option $=$ com content $\&$ view $=$ artic le\&id=11599\& Itemid=41691\&lang=en

3. Venkatesan A, Tunkel AR, Bloch KC, Lauring AS, Sejvar J, Bitnun A, et al. , International Encephalitis Consortium. 
Case definitions, diagnostic algorithms, and priorities in encephalitis: consensus statement of the international encephalitis consortium.Clin Infect Dis. 2013;57(8):1114-28. DOI: $10.1093 / c i d / c i t 458$ PMID: 23861361

4. Mathew S, Pandian JD. Stroke in patients with dengue.J Stroke Cerebrovasc Dis. 2010;19(3):253-6. DOI: 10.1016/j. jstrokecerebrovasdis.2009.05.003 PMID: 20434057

5. Wasay M, Khatri IA, Abd-Allah F. Arbovirus infections of the nervous system: current trends and future threats. Neurology. 2015;84(4):421-3. DOI: 10.1212/WNL.0000000000001177 PMID 25628429

6. Broutet N, Krauer F, Riesen M, Khalakdina A, Almiron M, Aldighieri S, et al. Zika Virus as a Cause of Neurologic Disorders. N Engl J Med. 2016;374(16):1506-9. DOI: 10.1056 NEJMp1602708 PMID: 26959308

7. Daep CA, Muñoz-Jordán JL, Eugenin EA. Flaviviruses, an expanding threat in public health: focus on dengue, West Nile, and Japanese encephalitis virus.J Neurovirol. 2014;20(6):5396o. DOI: $10.1007 /$ s13365-014-0285-z PMID: 25287260

\section{License and copyright}

This is an open-access article distributed under the terms of the Creative Commons Attribution (CC BY 4.0) Licence. You may share and adapt the material, but must give appropriate credit to the source, provide a link to the licence, and indicate if changes were made.

This article is copyright of the authors, 2016. 